\title{
The preliminary results of modern and past vegetation comparison by using different pollen monitoring methods in calcareous spring fens
}

\author{
Ansis Blaus, Triin Reitalu \\ Institute of Geology, Tallinn University of Technology, Ehitajate tee 5, 19086, Tallinn Estonia \\ e-mail: ansisblaus@ttu.ee; triin.reitalu@ttu.ee
}

Received: 24 April 2017/Accepted: 29 May 2017

\begin{abstract}
We investigate whether spring fens can be separated from raised bogs based on pollen data and study how much the pollen reflects the surrounding landscape and how much it reflects the local conditions in the fen or bog. Analysis is based on pollen trap and top sediment sample records obtained from Vedruka bog and Vesiku spring fen in Saaremaa island, Estonia.
\end{abstract}

Keywords: spring fen, pollen monitoring, vegetation diversity, paleoecology, pollen traps.

\section{Introduction}

Spring fens are among the most threatened biotopes of Europe. This type of wetland habitat harbours many relict and endemic species and is included in Natura 2000 habitat directive (code 7160). The conditions in spring fens are influenced by increasing human activities such as drainage, eutrophication and changes in agricultural practices, especially during the last 60-70 years. A better understanding of fen development and of associations between diversity and past human impact (drainage, grazing) and past climate in spring fen areas are of great importance for conservation planning of these rare wetlands and their unique biodiversity. The majority of the palynological work is based on either lake or bog sediments with the focus on surrounding landscape rather than on the sedimentary basin itself. In spring fens where the vegetation directly on the fen is rich in species, palaeoecological studies would also give us information about the fen development. Compari- sons between pollen trap data and upper sediment samples in spring fen and in close by bog area give us better understanding how much the spring fen pollen data reflect the surrounding landscape and how much they reflect the local conditions in the fen.

\section{Study area}

This research summarizes the preliminary results of analysis on the upper samples of the two sediment cores from Vesiku spring fen $\left(22.096721^{\circ} \mathrm{E} ; 58.325031^{\circ} \mathrm{N}\right)$ and from Vedruka bog $\left(22.060556^{\circ} \mathrm{E} ; 58.330278^{\circ} \mathrm{N}\right)$ - and from three pollen traps: one obtained from Vedruka bog (BogTrap) and two from Vesiku spring fen (FenTrap1 and FenTrap2). Vedruka bog and Vesiku spring fen are both situated on Saaremaa, the largest island in Estonia, are only two kilometers apart and should have similar pollen catchment area. 


\section{Materials and methods}

The uppermost samples used in the comparison with trap data were dated to 1978 in Vesiku spring fen and to 1969 in Vedruka bog. The pollen trap data were collected in 2016. The method for pollen trap installation follows the PMP homepage instructions (Hicks et al. 1996; www.pollentrapping.org). The sediment core and pollen trap material were treated with $10 \% \mathrm{KOH}$ followed by acetolysis method. Prepared pollen slides were counted under the microscope using pollen collection from Tallinn Technical University, Department of Geology, (Reille 1992) and (Beug 2004) for reference. Minimum of 1000 pollen grains were counted per sample. The pollen trap data will be used to compare with the contemporary vegetation composition to be collected in summer 2017.

To study the differences in pollen composition among the traps and sediment samples, we used hierarchical clustering with Bray-Curtis dissimilarity measure (Bray \& Curtis 1957).

\section{Results}

Comparing the uppermost parts of the Vesiku and Vedruka cores and all three pollen traps, the general features of pollen distribution are similar. The percentages of arboreal pollen are on average higher in the trap data than in the core sample data ( $92 \%$ in traps vs $84 \%$ in core samples). The non-arboreal pollen types are more numerous in the traps but their percentages on average are significantly lower (11.5\% in core vs $7.5 \%$ in traps). The results of cluster analysis (Fig. 1) shows that the samples from Vedruka bog (BogSed, BogTrap) are separated from the samples from Vesiku fen (FenSed, FenTrap1, FenTrap2), suggesting clear differences between bog and fen pollen samples.

The main taxa that drive the differences between the sites are Calluna vulgaris that practically did not occur in fen samples, but composed approximately $1.8 \%$ of bog samples. The Sphagnum composed $0,8 \%$ of bog pollen percentage but was not observed in fen pollen records. In addition, Cyperaceae showed significantly higher pollen percentages in fen samples $2.6-14 \%$ compared to the $1 \%$ in bog samples. From the arboreal taxa, Betula showed twice as large pollen percentages in bog samples $-9 \%$ in fen vs $21 \%$ in bog.

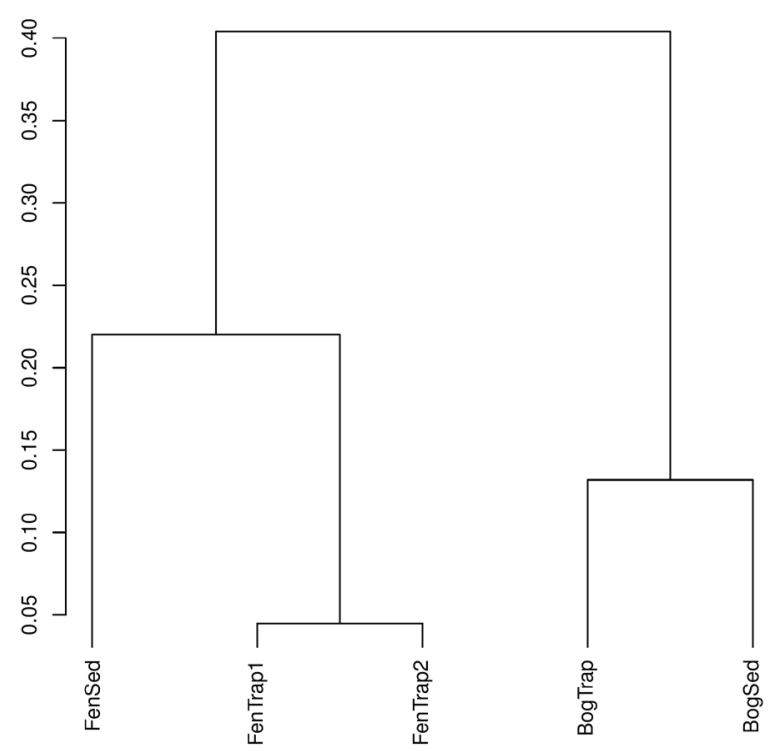

Figure.1. Results hierarchical clustering of bog and fen samples. The $\mathrm{x}$-axis shows Bray-Curtis dissimilarity

\section{Discussion}

Calluna and Sphagnum are both characteristic to the acidic conditions of bog vegetation and calcareous spring fens are known to be the habitat for several sedge species (Cyperaceae). Our results are therefore hardly surprising from the botanical point of view but they confirm our expectations that based on pollen analysis methods, it is possible to distinguish fen and bog type vegetation and that sedimentary pollen data could give us information on fen development.

There are not many papers focused on spring fen pollen records (Hajek et al. 2012; Jamrichová et al. 2014; Koczur \& Nicia 2013) and this is the first time it has been done in Estonia. Our preliminary results will be accompanied by detailed vegetation study and moss polster data shedding more light to the fen/bog differences.

\section{Acknowledgements}

The authors acknowledge the financial support from Estonian Ministry of Education and Research (PUT1173). 


\section{References}

Beug H.J., 2004, Leitfaden der Pollenbestimmung für Mitteleuropa und angrenzende Gebiete. Verlag Dr.Frierdrich Pfeil, München.

Bray J.R. \& Curtis, J.T., 1957, An ordination of upland forest communities of southern Wisconsin, Ecological Monographs 27: 325-349.

Hájek M., Hakera P. \& Hájková P., 2002, Spring fen vegetation and water chemistry in the Western Carpathian flysch zone, Folia Geobotanica 37: 205-224.

Hicks S., Ammann B., Latałowa M. \& Pardoe H., 1996, European pollen monitoring programme, Project description and guidelines, Oulu University Press, Oulu, Finland.
Jamrichová E., Hájková P., Horsák M., Rybníčková E., Lacina A. \& Hájek M., 2014, Landscape history, calcareous fen development and historical events in the Slovak Eastern Carpathians, Vegetation History and Archaeobotany 23: 497-512. DOI:10.1007/s00334013-0416-0

Koczur A. \& Nicia P., 2013, Spring fen Scheuchzerio-Caricetea nigrae in the Polish Western Carpathians - vegetation diversity in relation to soil and feeding waters, Acta Societatis Botanicorum Poloniae 82(2): 117-124. DOI: 10.5586/asbp.2013.009

Reille M., 1992, Pollen et spores d'Europe et d'Afrique du Nord, Laboratoire de Botanique historique et Palynologie, Marseille, France. 